\title{
REDES TRANSNACIONAIS DE MOVIMENTOS SOCIAIS NA AMERICA LATINA E O DESAFIO DE UMA NOVA CONSTRUÇÃO SOCIOTERRITORIAL
}

\author{
Breno Bringet \\ Alfredo Falero ${ }^{* *}$
}

\begin{abstract}
O presente artigo parte de duas considerações: a necessidade de estabelecer diálogo interdisciplinar entre a geografia e a sociologia sobre a problemática do território e da espacialidade da política; e a constatação que a construção de redes transnacionais de organizações e movimentos sociais constitue dimensão-chave nos processos latino-americanos atuais. À luz dessas considerações os autores examinam as redes transnacionais construídas a partir de movimentos sociais na América Latina, com base no enfoque socioterritorial. Sob esta perpectiva são analisados o Movimento dos Trabalhadores Rurais Sem Terra - MST, do Brasil e a Federação Uruguaia de Cooperativas de Moradia por Ajuda Mútua-FUCVAM, do Uruguai. Na análise serão observadas as convergências, a formação de espaços contra-hegemônicos e os desafios enfrentados por experiências dessa natureza na busca de projeções emancipatórias, no século XXI.

Palavras-chave: movimentos sociais, redes e direitos supranacionais, territorialidades, hegemonia, América Latina.
\end{abstract}

\section{INTRODUÇÃO}

Nos últimos anos, consolidou-se um duplo processo de expansão da política: por um lado, a proliferação de intercâmbios políticos de baixo, ou seja, a exploração da arena política para além do marco institucional-partidista, abrindo espaços, identidades e formas de ação coletiva que se desenvolvem dentro da chamada sociedade civil, à margem, mas de modo suplementar à política tradicional. E, por outro lado, a irrupção da política de fora, no âmbito supranacional, transgredindo as fronteiras nacionais e rompendo com a territorialidade da política no Estado-nação (Arditi, 2005; Bringel; Echart; López, 2008).

Dois ângulos de análises aparecem como chaves para a aproximação desse duplo processo.

\footnotetext{
* Pesquisador do Departamento de Ciência Política III da Universidad Complutense de Madrid.

Campus de Somosaguas s/n - 28223 - Pozuelo de Alarcón - Madrid - Espanha. brenobringel@hotmail.com

* * Professor da Faculdade de Ciências Sociais da Universidade de la República do Uruguai.

Avenida Constituyente, $1502-5^{\circ}$ piso. Montevideo -

Uruguay. alfredof@adinet.com.uy
}

Por um lado, é preciso contar com instrumentos conceituais que nos permitam examinar o caráter dos agentes sociais participantes e o espaço social do qual emergem, as práticas sociais que realizam, a construção de subjetividades coletivas que implicam e as dinâmicas que se desencadeiam, assim como os conflitos, as contradições e as tensões que se dão nessa construção.

Por outro lado, é necessária uma aproximação socioterritorial. Por exemplo, é relevante fazer notar que o Estado-nação se desconstrói como marco referencial essencial para a política dos movimentos sociais (num processo de transnacionalização da política e do território), mas, assim como antes, nem tudo era território estatizado, nem tudo que emerge é estritamente transnacionalizado. Inclusive nos lugares onde os vetores da globalização são mais operativos e eficazes, o território habitado cria novas sinergias e acaba por impor ao mundo uma revanche (Santos, 2005, p.138).

Tendo presente ambos os planos de análises, e assumindo a necessidade de um diálogo interdisciplinar que permita articular os planos 
geográficos e sociológicos, este artigo examinará as redes transnacionais que construíram alguns movimentos sociais na América Latina. Para isso, serão considerados dois casos diferentes: o Movimento dos Trabalhadores Rurais Sem Terra (MST), como movimento de base rural no Brasil, e a Federação Uruguaia de Cooperativas de Moradia por Ajuda Mútua (FUCVAM), como movimento de base urbana no Uruguai. Em ambos os casos, a preocupação central é mapear a formação de redes transnacionais, em um sentido amplo.

Finalmente, procurar-se-á transcender os estudos de caso, para estabelecer as dimensões socioterritoriais dessas dinâmicas de forma mais generalizada, ainda que sempre considerando as especificidades existentes na América Latina. Finalmente, observar-se-ão as convergências, a formação de espacialidades contra-hegemônicas e os desafios que esse tipo de experiências enfrenta em suas lutas em pleno século XXI, na procura de projeções emancipatórias.

\section{ALTERNATIVAS SOCIETÁRIAS, SUBJETIVI- DADE COLETIVA E O DESAFIO DE PENSAR PARAALÉM DO ESTADO-NAÇÃO}

\section{A construção de direitos, hegemonias e o Es- tado-nação}

A construção de direitos está vinculada às transformações sociais que se caracterizam como o surgimento da modernidade européia e que inclui um suposto político territorial fundamental, que éo Estado nacional. Poder-se-ia dizer que se trata de uma violenta produção política dos limites territoriais, o que faz a soberania estatal adquirir uma função capital. A relevância que esse conceito de soberania adquire, a nosso ver, é que recorta a natureza pulsional de qualquer movimento que a supere (Negri, 1994). Apresenta-se, nesse sentido, como limitante, fixadora do que começa a denominar-se sociedade civil.

Essa sociedade civil, localizada nos limites territoriais de um Estado, foi construída conceitualmente através de numerosos trabalhos, ${ }^{1}$ mas é possível gerar um esquema a partir de duas alternativas analíticas básicas. Por um lado, o conceito se localiza na abstração do contrato ou pacto fundacional, peça chave da construção de Hobbes, quando começava a expressar, no âmbito teórico, essa dicotomia entre sociedade civil e Estado, que terminaria se generalizando. Há uma variação posterior - não uma inflexão - com Locke, que, embora utilize, como Hobbes, a noção como sinônimo de sociedade política, elabora uma distinção entre uma ordem social pré-estatal e de governo. Aqui, a sociedade civil se encontra já constituída pela união dos cidadãos, que, em um segundo momento, criam, por sua vez, o Estado (Serrano, 1999). Assim, a alternativa liberal submerge suas raízes nessa tradição ius naturalista e considera esse espaço social como uma pluralidade atomística de indivíduos e grupos, onde qualquer princípio unificador é exterior a tal pluralidade. Além do mais, recorda que, sem um Estado nacional, é impensável uma relação entre mercado nacional e mercado internacional, que é o que faz possível a acumulação originária.

Por outro lado, deve-se resgatar a linha teórica fundamentalmente trabalhada por Gramsci no século XX, mas que reconhece antecedentes longínquos em Hegel. A distinção hegeliana de Estado repousa no tipo de interesse que lhe dá origem: ações que derivam de um interesse do tipo geral, no caso do Estado, e ações que derivam de um interesse particular, no caso da sociedade civil, que, desse modo, abrange a esfera econômica e as necessidades materiais. Posteriormente, as alusões e o sentido que Marx lhe atribui somente aparecem

${ }^{1} \mathrm{Na}$ última década, teve grande difusão, na América Latina, a obra de Cohen e Arato (1992), que constitui uma importante contribuição para demonstrar a utilização do conceito de sociedade civil na teoria política moderna (de fato, o conceito de sociedade civil continua alimentando os principais paradigmas da teoria social e política contemporânea). No entanto, como argumentaremos em seguida, ao discorrer sobre o potencial do conceito de "sociedade civil", não podemos, com esta obra, pensar as articulações transnacionais da sociedade civil, tampouco desenvolver uma estrutura da sociedade civil convergente com a transformação social e a busca da emancipação, já que esta cai em uma linha reformista que, embora inclua suas estruturas de pluralidade, se centra em seu potencial para a expansão democrática sob os regimes democrático-liberais, nublando as apostas democráticas mais radicais. 
em esporádicos vôos teóricos que não lhe conferem uma carga explicativa particular e que perdem relevância no conjunto, frente a outras categorias explicativas. O centro explicativo, do ângulo que desenvolvemos, passa a estar em seu conceito de proletariado, visto como um leque de setores da classe submetida à exploração capitalista e potencialmente unificado como sujeito de transformação.

Gramsci recuperará de Hegel, como a dinâmica de interesses particulares impõe, uma evolução teórica e prática da cultura e observará como a sociedade civil não deixa de ser um campo de disputa entre classes, um campo de disputa hegemônico, ainda que a hegemonia não se localize somente aqui, mas também no Estado. De fato, Perry Anderson, há alguns anos, colocou de forma manifesta as oscilações de sentido que têm esses conceitos em Gramsci (Anderson, 1987, 1988). Mas tais críticas, entre outras, não inibem a necessidade de se resgatar um âmbito - mais complexo que antes - de constituição de sujeitos sociais como arco de atores que promovem a subversão da ordem estabelecida. E, nesse sentido, o eixo central não está tanto na sociedade civil, mas no conceito de hegemonia como expressão nuclear de um projeto estratégico, apropriação subjetiva e real de elementos de transformação social, fusão de elementos intelectuais e morais de agregados diversos que não perdem sua identidade num processo dinâmico, nem sempre estruturado.

Frente ao predomínio da lógica dominante, a expressão nova hegemonia formula o âmbito onde se configuram as práticas - classistas - encaminhadas a modificá-lo. Isso implica que a criação e a abertura de opções se manifestam em aspirações sérias e desejáveis que, por sua vez, enriquecem as decisões coletivas. Não se trata, aqui, de caracterizar como se estabelece o consenso - particularmente o que é imposto nos acríticos contextos atuais de socialização, os meios de comunicação -, nem as formas sutis de repressão na sociedade atual, mas sim de examinar como, a partir de Gramsci (1985), mais que nos restringir ao conceito de sociedade civil, é possível contar com uma concepção de hegemonia para o século XXI.
Tendo presente as transformações globais ocorridas e em curso, e particularmente a realidade latino-americana atual, fundamentamos, em outros trabalhos, a escassa capacidade explicativa que aquele conceito oferece hoje e como a Sociologia contemporânea pode fornecer alternativas que permitam apontar, com mais concreção, para o espaço em que emerge a construção de direitos e onde se configura uma nova hegemonia (Falero, 2008). Assim, podemos estabelecer uma primeira premissa: a sociedade civil regional ou global (como se começou a postular há alguns anos, por Kaldor, 2005 , entre outros), ainda que trate de superar a matriz estadocêntrica da sociedade civil, constitui, na maioria dos casos, uma prolongação linear de conceitos formulados em outro contexto histórico e não contribui com ferramentas conceituais para se entender a convergência dos processos transnacionais em curso entre movimentos e organizações sociais.

Pode acontecer de maneira diferente com o conceito de hegemonia, já que tais agentes aparecem como uma das principais chaves na construção e expansão de direitos e na capacidade, em conseqüência, de promover novos fatos políticos e culturais de transcendência. Entre eles, os nexos transnacionais adquirem uma importância decisiva, apesar de suas debilidades e fortalezas conjunturais. No entanto, antes de entrar nesse plano, é necessário fixar outros elementos conceituais.

Quando se fala de direitos, nas ciências sociais, é freqüente recorrer ao trabalho clássico de meados do século XX de Theodor H. Marshall Ciudadanía y clase social e mencionar os três níveis que têm uma ordem cronológica: civis, políticos e sociais (Marshall; Bottomore, 1998). Sua tese é uma resposta a Alfred Marshall em The future of working classes, de 1873, pensador liberal que defendia uma concepção estreita de cidadania. Sabemos que T. H. Marshall explica como os direitos civis que implicam a liberdade da imprensa e da palavra, de movimento e de propriedade se instauram no século XVIII; os direitos políticos como a extensão do sufrágio e de associação e organização, generalizam-se ao longo do século XIX; 
e, finalmente, os direitos sociais relacionados à extensão de cidadania e igualdade, como o direito à educação, se estendem no século XX.

Apesar da contribuição de delimitar as determinações modernas de cidadania e de dar uma idéia de suas práticas num processo histórico (Coutinho, 1999), trata-se de uma visão evolucionista e simplista, com um ar de inevitabilidade histórica, que não tem em conta a diferença de classes, tampouco os diferentes contextos. Não cabe dúvida alguma de que o esquema de evolução de direitos não se reproduz assim em grande número de países, e quando se analisa a história da América Latina se vêem as complexidades de extrapolar esse esquema sem maiores nuances. Como recorda Anibal Quijano (1991), a ilustração européia marca uma divisão entre uma racionalidade como promessa de liberação e uma racionalidade como dispositivo instrumental de dominação; e ambas se transmitiram na subjetividade latino-americana como modernidade. Entre os ricos e variados elementos que nutrem a subjetividade social, a modernidade regional se conformou com a primazia da segunda, para o qual a hegemonia dos Estados Unidos, no século $\mathrm{XX}$, foi chave. O fato é que a modernidade não terminou se associando a uma cidadania ativa como construção expansiva de igualdade e liber-

o acesso à moradia, no âmbito urbano, no caso da FUCVAM. Em última instância, a diferença entre uma perspectiva mercantilizadora e uma desmercantilizadora está no lugar que ocupa o ganho ou lucro como lógica central de resolução da necessidade.

Chegamos, assim, à segunda premissa: os movimentos sociais têm uma enorme importância para construir subjetivamente a resolução de uma necessidade como um direito e não como produto de uma atividade mercantil. Em tal construção, esses agentes têm o desafio de incorporar o plano transnacional de atuação, e nós a tarefa de examinar as complexidades e contradições que aparecem nesse novo espaço de ação. E, para fazê-lo, torna-se necessário um ângulo de análise nãoeurocêntrico, que nos permita uma aproximação dessa realidade, na América Latina.

\section{Direitos, subjetividade coletiva e o desafio do plano transnacional de atuação dos movimen- tos sociais}

Denominamos subjetividade social ou coletiva uma perspectiva de análises que, com uma inspiração gramsciana já aludida e com o aporte de diversos autores - como é o caso de Hugo Zemelman (1989, 1992, 1996) e Emma León (Leon; Zemelman, 1997) -, refere-se à assimilação de elementos racionais e irracionais, cognitivos, valorativos, e à construção de formas de ver e estar no mundo a partir da prática social dos agentes sociais. Muitos agentes, na sociedade, constroem subjetividade social: os meios de comunicação, as organizações sindicais, as organizações político-partidárias, os agentes nos lugares de trabalho (aliás, a empresa se converteu num espaço renovado em tal sentido) ou no bairro, os movimentos sociais.

Trata-se de uma dinâmica de interação com dupla direção: internalização e externalização. Os indivíduos constroem sua personalidade, se socializam com idéias, valores, etc., interiorizando elementos, ao mesmo tempo em que os externalizam, 
ou seja, compartilham-nos com outros. ${ }^{2}$ Por isso, tos grupos de poder se posicionam frente a eles. é possível sustentar que, a partir da experiência Como afirma Boaventura de Souza Santos (1998), cotidiana, das histórias de vida e de luta, também o princípio da subjetividade é muito mais amplo se gera uma trama latente, a capacidade e a potencialidade de construir o alternativo (Falero, 2008). Procuramos indicar aqui o aprofundamneto na articulação entre resolução de necessidades, experiências sociais e construção de horizontes de possibilidades (Leon; Zemelman, 1997), tendo presente determinados contextos espaço-temporais. Trata-se de enfatizar a idéia de construção, de movimento (e não de percepções cristalizadas), do potencial envolvimento em processos coletivos que, por sua vez, produzem subjetividade sociale de atribuições de significação e sentido que os próprios atores vão dando sobre um conjunto de necessidades sociais.

Com respeito ao que foi dito anteriormente, pode-se dizer que o terreno da subjetividade coletiva implica um campo de batalha permanente na América Latina e que vem assumindo novas formas nos últimos anos. Desse modo, a conformação de agentes como os movimentos sociais nunca pode ser vista como algo produzido, mas como uma produção permanente de uma sucessão de conjunturas históricas e de disputas espacializadas. As posturas e os espaços de atuação variam no conflito, a tensão entre interesses de todo tipo sempre aparece, e o resultado do movimento sempre é indeterminado. Existe uma extensa bibliografia e diferentes abordagens sobre os movimentos sociais na América Latina, mas uma das aproximações possíveis, que agora assumimos, tem a ver com sua capacidade de construir significados de resolução de necessidades, de direitos, num sentido emancipatório, em suma, de alternativas societárias.

$\mathrm{O}$ impulso atual de demandas populares por velhos e novos direitos sociais negados não pode ser separado da expansão de uma subjetividade coletiva de mudança social e de como distin-

\footnotetext{
${ }^{2}$ A relação entre o âmbito da vida cotidiana e o conjunto da vida social, esse processo que implica o que designamos como internalizacão e externalização, têm diferentes implicações segundo a corrente teórica utilizada, mas, de alguma maneira, sempre implica uma dinâmica com ambos os aspectos.
}

que o princípio da cidadania. A teoria liberal promoveu a redução da participação política ao exercício do direito do voto, e qualquer outra forma foi e é desestimulada. Até mesmo a simples demanda de ampliação da participação, tão recorrente nos dias de hoje e defendida tanto pelas instituições como por algumas organizações sociais, não supõe necessariamente verdadeiras transformações reais. É assim como a participação, entendida como construção potencial de cidadania, porém limitada à expansão de uma subjetividade coletiva na potencialidade mencionada, converte-se em sinônimo de reformismo social-democrata

Terceira premissa: entre as práticas sociais e a construção de direitos, há um processo complexo de conscientização de uma situação ou de um conjunto delas, que representa uma gama de percepções, representações, idéias, sentimentos, expectativas, desejos. Esse processo coletivo, de elaboração, socialmente condicionado, e que supõe uma ponte para uma dinâmica de envolvimento com o objetivo de alcançar os direitos sociais, é o que chamamos construção de uma subjetividade coletiva ou social. Isso é igualmente válido para se construir uma idéia alternativa do transnacional e da América Latina como espaço regional de integração. A história fornece numerosos exemplos de períodos em que se construíram subjetividades coletivas de resistência, de emancipação e de luta, que foram adquirindo diferentes significados sociais. Potencialmente (dependendo dos agentes sociais), a América Latina pode projetar-se subjetivamente com maior concreção como referente do alternativo.

Essa perspectiva de expansão ou limitação de uma subjetividade coletiva, no sentido regulador ou emancipatório, permite visualizar igualmente a importância das produções simbólicas que determinados grupos de poder constroem a partir da capitalização de recursos. Nesse sentido, é importante recordar algumas contribuições de Bourdieu (2005). Se falarmos de um setor da eco- 
nomia, um grupo (entendido na conformação de proximidades num espaço social) pode fazer passar ou impor seus interesses específicos como benefícios de toda a sociedade. Da mesma forma, quando se vê a economia como esfera autônoma, separada do mundo social, quando o mercado aparece como a melhor maneira de organizar o social, quando se associa a globalização com redução do tamanho do Estado e do livre comércio, ou ainda quando se constrói a integração regional como uma questão meramente técnica de negociadores especialistas, se está frente a produções simbólicas dominantes no contexto atual.

Do mesmo modo, quando se toma o conceito de poder simbólico no campo global, pode-se analisar como os Estados Unidos vendeu sua visão nacional como universal, promovendo o que, há anos, se identificava como imperialismo cultural. Essa universalização de particularismos de uma experiência histórica singular (que, por exemplo, chegou a conformar uma concepção empresarial da vida), não reconhecível como tal, constitui um exemplo de violência simbólica.

Também, a partir de Bourdieu, pode-se dizer que, enquanto os habitus vão combinando $e x$ periências sociais, os coletivos e sua potencialidade de transformação social são tanto o produto de nossa subjetividade já construída como das novas situações que se apresentem ou estão por construir-se. No entanto, as experiências sociais e a formação de habitus estão vinculadas aos espaços sociais em que o indivíduo se move. Portanto a subjetividade pode continuar sendo colocada como uma questão relativa não somente à estabilidade, mas também à mudança. Mas isso só é possível com a condição de se perceberem tendências claras das mudanças estruturais em curso, ou seja, de como se especificam as novas relações de poder nas sociedades latino-americanas que são estudadas. Nessas relações, o simbólico ocupa um lugar importante na forma de dominação, na luta pela produção e difusão de visões do mundo, nas lutas simbólicas específicas que ocorrem nos distintos campos.

Assim, “o poder simbólico é um poder de construção da realidade que inclina a estabelecer uma ordem gnosiológica: o sentido imediato do mundo (e, em particular, do mundo social) supõe aquilo que Durkheim chama o conformismo lógico..." (Bourdieu, 2005, p. 9). Como se vê, diferentemente da tradição marxista do conceito de ideologia, que privilegia a função política, aqui se enfatiza a função gnosiológica. O mundo social não funciona em termos de consciência, mas sim em termos de práticas, mecanismos, etc. Ao utilizar a doxa aceitamos muitas coisas sem conhecê-las, dizia Bourdieu num encontro com Terry Eagleton (Bourdieu; Eagleton, 2000). O poder se naturaliza com a doxa, ou seja, coisas que os indivíduos aceitam sem saber. Se a doxa pode ser equiparável ao sentido comum, o conceito de poder simbólico pode operar como o conceito gramsciano de hegemonia ou, talvez, como uma reelaboração não buscada do mesmo conceito, a partir de uma relação micro ou macro social. Seria desde um duplo processo de reconhecimento desse poder, por um lado, mas também de desconhecimento de como opera, por outro. Dessa maneira, pode-se reproblematizar o que abusivamente se generalizava como um problema de consciência ou de não consciência.

Não obstante, tampouco se trata, a nosso ver, de abusar do conceito de sentido prático que o autor introduz (Bourdieu, 1997), como se toda a visão supusesse, de forma onipresente, a lógica prática, pré-reflexiva, de atuação num mundo que impõe sua presença e suas urgências. Em outras palavras, sem negar que existe esse sentido prático, que permite economizar reflexão e energia na ação, forma parte imprecisa do habitus do agente e, portanto varia em função dele. Dito isso, este ponto é muito importante, pois nos permite recordar que os movimentos coletivos por determinados direitos adquirem força quando se articulam a objetivos práticos que dão sentido cotidiano à luta.

Esse sentido prático também pode incluir a afirmação de uma dignidade coletiva. Por exemplo, a FUCVAM articula, no Uruguai, um sentido prático dos indivíduos que integram o movimento - aceder à moradia -, com outras considerações 
sobre o caráter da ajuda mútua e um projeto de sociedade. Da mesma maneira, a luta pela terra do MST brasileiro e outros movimentos não podem ser entendidas como algo abstrato, mas sim enlaçados à cotidianidade e a um espaço geográfico ou território específico. Há um sentido prático que coexiste com os processos de socialização e territorialização.

Em resumo, a construção de subjetividades coletivas está atravessada por batalhas simbólicas que se produzem em toda a sociedade. As lutas, nesse sentido, podem ser individuais - a do intelectual que se nega a ser arrastado na corrente do pragmatismo, à custa de sua sobrevivência como tal - ou lutas coletivas como as ocorridas na América Latina desde os anos 1990, contrárias ao projeto econômico do chamado neoliberalismo. Para tais lutas, não somente se trata de acumular capital simbólico, mas sim de gerar o que pode denominar-se eficácia simbólica, que depende da relação entre proposta e realidade. E, para que um poder seja legítimo, deve naturalizar-se, deixar de ser reconhecido como o que é; avalizar-se de maneira tácita em vez de explícita.

Isso nos leva à nossa quarta e última premissa: a conformação de redes transnacionais supõe também batalhas simbólicas. As subjetividades coletivas também se constroem sobre o significado de idéias como nacionalidade, patriotismo e soberania, que, de fato, conservam muita vigência e são partes dos conflitos, ainda que se previnam as fortes contradições a que estão sujeitas na atualidade. Há de se ter em conta que nascer dentro de uma sociedade supõe avaliar as relações sociais que alí operam, através de um conjunto de sinais coletivos compartilhados e que se diferenciam de outros, mas inclusive de poderosos sentimentos vinculados a um espaço geográfico específico, forçados a se transformarem quando operam mecanismos pós-nacionais ou transnacionais tão fortes como os atuais.

A conformação de direitos pós-nacionais se torna particularmente decisiva em contextos de integração regional, de acordo com uma perspectiva não eurocêntrica de integração, isto é, substan- tiva e não meramente dependente do amadurecimento do projeto econômico num futuro indeterminado. Pelo contrário, qualquer projeto mínimo de integração, que postule a dissolução de barreiras comerciais no contexto global atual, deve integrar, no chamado sentido comum, os temas que levem à geração de direitos para além de fronteiras nacionais (Falero, 2006).

O plano transnacional de atuação supõe, em conseqüência, processos de resignificação permanente sobre esse novo âmbito de atuação e, portanto, étambém um terreno de disputa hegemônico. Desse modo, na construção de redes e articulações transnacionais ou pós-nacionais, não se deve deixar de observar um processo contraditório como todo processo social -, em que se pretende estabelecer a potencialidade e a capacidade de construção de outra hegemonia. Uma vez nesse ponto, e partindo das quatro premissas mencionadas, aportamos alguns elementos para examinar casos concretos de conexões e lógicas de cooperação entre atores sociais de países diferentes e a capacidade conjunta de impulsionar alguns direitos sociais, tendo em conta o horizonte transnacional. No entanto, ainda nos falta aprofundar em alguns instrumentos conceituais mais específicos do plano socioterritorial e as dinâmicas reticulares sobre as quais nos ocuparemos nas próximas linhas.

\section{DES-EN-RED-ANDO AS AÇÕES COLETIVAS TRANSNACIONAIS DOS MOVIMENTOS SOCIAIS NA AMÉRICA LATINA}

\section{Novas horizontalidades, sociabilidades e territorialidades no marco supranacional}

Conforme dizíamos anteriormente, pensar o terreno supranacional como marco das lutas sociais não é algo recente, já que poderíamos remontar suas origens, inclusive, ao internacionalismo operário do século XIX. Tampouco podemos cair na armadilha de interpretar as lutas e movimentos sociais num âmbito transnacional com uma simples transferência, para o supranacional, das fer- 
ramentas conceituais utilizadas para as dinâmicas e lógicas doméstico-nacionais.

Tendo em conta a complexidade do movimentismo para além das fronteiras do Estado-nação, o que nos interessa destacar, como traço distintivo no transnacionalismo das lutas dos movimentos sociais contemporâneos, são as convergências de identidades e solidariedades, as novas formas de organização, a construção de subjetividades coletivas que trascendam o marcoreferencial local ou nacional. Elas estão unidas a uma nova estrutura de oportunidade políticas para a política internacional e à crescente complexidade da questão territorial através das múltiplas territorrialidades implicadas nas lutas sociais contemporâneas que imbricam, de diferentes maneiras, o local, o regional-nacional, o regional-internacional (blocos), o nacional e o global (Bringel, 2006; Haesbaert; Milani; Laniado, 2006; PortoGonçalves, 2005; Tarrow, 2005).

A globalização, como pano de fundo - e também a atuação dos movimentos contra a globalização neoliberal, como aquelas vozes e iniciativas de movimentos e organizações sociais que, através de vínculos, redes e alianças glocais, lutam por um mundo melhor -, contribuiu decisivamente para esse deslocamento dos espaços de intervenção política, redimensionando os próprios mecanismos de conflito e as formas de organização dos movimentos sociais, que giram para novas di-visões e pugnas no espaço mundial (e regional, no caso latino-americano), sob um complexo de idéias de redes e projeções hegemônicas e contra-hegemônicas. Isso leva a que assistamos, em grande medida, a uma irrupção dos movimentos sociais como novo ator internacional (Echart, 2008).

No meio das transformações na organização territorial da atividade econômica e do poder político-econômico, o processo de globalização também levou à mundialização do espaço geográfico, o que supõe, entre outras coisas, a transformação dos territórios nacionais em espaços nacionais da economia internacional, a exacerbação das especializações produtivas no âmbito espacial, a produtividade espacial na eleição das localidades, a ten- são crescente entre localidade e globalidade e o recorte horizontal e vertical dos territórios (Santos, 2005, p. 147).

Desse modo, a tendência global hegemônica impõe a união vertical e hierarquizada dos lugares (por exemplo, os créditos internacionais postos à disposição dos países mais pobres, para permitir que se estabeleçam redes a serviço do grande capital) e das relações sociais, ainda que o impulso contra-hegemônico de vinculação horizontal dos lugares (e de horizontalidade nas formas organizativas) também assiste a um renascimento em tempos de globalização. No caso latino-americano, quando, por exemplo, os camponeses se organizam num movimento social transnacional, como a Via Campesina, ou numa rede de movimentos sociais, defendendo seus interesses de forma articulada e duradoura no tempo e fomentando novas formas de produção, de consumo e de comercialização que trascendem a lógica puramente econômica, tecem-se novas horizontalidades. Nestas, embora ganhem uma dinâmica reticular transnacional em sua forma organizativa que afeta o alcance de suas práticas, está presente uma forte base territorial local/nacional, onde também atuam e canalizam os conflitos ao espaço público.

Estas redes de movimentos sociais também geram, a partir desses novos recortes horizontais, novas sociabilidades, através da instituição de outras formas de relações sociais, de vínculos comunitários e afetivos, solidários e de reconhecimento mútuo (ou ajuda mútua, como diz o próprio nome da FUCVAM). Trata-se de iniciativas coletivas intensas (re)criadas continuamente nas próprias lutas na busca de novos sentidos para as práticas sociais, em muitos casos, como no do MST, fortemente arraigadas numa educação de inspiração freireana em movimento, transformadora e dialógica.

Isto contribui para a construção de novas subjetividades, entendidas, tal como argumentamos anteriormente, como as percepções, representações, idéias, sentimentos, expectativas ou desejos construídos pelos sujeitos sociais em suas práticas cotidianas, nas experiências vividas. O maior esforço ou complexidade para pensar as subjetivi- 
dades sociais ou coletivas, tecidas pelos movimentos sociais, no âmbito supranacional, está ligado a pensar o locus da construção dessas subjetividades, posto que, muitas vezes, se associou, de forma equivocada, as redes de movimentos à desterritorialização.

Como recorda Haesbaert (2006, p. 279), a estrutura de uma sociedade em rede não é, obrigatoriamente, sinônimo de desterritorialização, posto que, em geral, leva a novas territorializações, pelo que territorializar-se significa também, na atualidade, construir e (ou) controlar fluxos ou redes e criar referenciais simbólicos num espaço em movimento-e nos movimentos (sociais). É assim como se projetam e se constroem tambén novas territorialidades. Se concordarmos, como PortoGonçalves (2001, p. 82), que as territorialidades são instituídas por sujeitos sociais em situações históricas determinadas, que condicionam os caminhos possíveis ou bifurcações do devenir histórico, podemos afirmar que, frente aos novos padrões de organização do espaço (ou as novas geografias do poder, em termos de Sassen, 2001), as tensões e a confrontação de interesses entre o poder político-econômico hegemônico e as lutas sociais de povos, organizações ou coletivos estão na base das pugnas por territorialidades.

Nessa disputa pelo espaço, a luta pela terra do MST (ou de qualquer movimento social que tenha o território como referente em sua luta), por exemplo, passa por romper com a territorialidade do latifúndio, do poder econômico e do Estado territorial moderno, para tecer novas territorialidades e racionalidades produtivas. Nesse sentido, cada vez mais, o MST luta não somente pela terra, mas também pelo território, pela instituição de novas territorialidades.

Além do mais, são significativas as recentes articulações entre o nível local, nacional ou regional, os territórios tradicionais, e o poder econômico global, como no caso das inversões de Bill Gates ou George Soros em terras brasileiras, depois do acordo entre Lula e Bush em março de 2007, para a produção de etanol, fomentando o agronegócio, exemplo ilustrativo da transnacionalização das ten- sões em torno das territorialidades. As redes transnacionais de movimentos sociais contribuem, por exemplo, para visibilizar, num âmbito global, os ataques da burguesia contra as territorialidades campesinas ou indígenas, entre outras, em distintas escalas, num complexo conjunto de idéias e interesses, redes e projetos contrapostos, assim como para articular interesses de coletivos num marco supranacional mais amplo, pelo que são igualmente afetados em seus diferentes contextos e territórios.

\section{A construção de uma aproximação socioterritorial: redes transnacionais, movi- mentos sociais e território}

Na América Latina, emergem, nos anos de 1990, redes de movimentos sociais com as seguintes características: articulação de atores e movimentos sociais e culturais, pluralismo organizacional e ideológico, atuação nos campos cultural e político e um marcado traço transnacional (Scherer-Warren, 2005a, p. 119). Tendo em conta também a década de 1990 como um marco temporal de irrupção dessas redes, Milani e Laniado (2006) consideram as redes transnacionais de movimentos sociais como a expressão de um novo sujeito social, que deslocou sua escala de intervenção política a fim de lutar pela justiça social global. A essa ampla definição, próxima ao movimento anti-globalização (e, em particular, às redes tecidas no seio do Foro Social Mundial), interessa-nos acrescentar as especificidades das redes e unidades de ação criadas por diferentes movimentos sociais latino-americanos (exemplos paradigmáticos seriam o dos camponeses, através da Coordinadora Latinoamericana de Organizaciones del Campo (CLOC) e da Via Campesina, o movimento feminista com a Marcha Mundial das Mulheres (MMM), a luta contra a ALCA e os Tratados de Livre Comércio (TLC) com a Aliança Social Continental (ASC).

Em particular, pretende-se pensar o lugar das redes transnacionais de movimentos sociais no marco de uma reestruturação espacial da América Latina como região, como um referente de re- 
sistência espacial supranacional, num contexto onde estão imbricados projetos de integração regional de baixo, ou para os povos, pelo que apostamos numa uma abordagem para onde confluam a análise dos agentes sociais participantes, o espaço social do qual emergem, as práticas sociais e ações coletivas que realizam e as subjetividades coletivas e dinâmicas que desencadeam, com um olhar que vislumbre a convergência transnacional de suas práticas, assim como as horizontalidades, sociabilidades e territorialidades que vão sendo construídas, pensando o lugar (espaço geográfico) das disputas por hegemonias e a mudança social.

Nesse sentido, nas décadas de 1970 e 1980, os movimentos sociais da região atuavam fundamentalmente no interior de suas respectivas fronteiras nacionais, envolvidos na luta pela redemocratização e pelos direitos básicos, num contexto quase generalizado de transições, a partir de governos autoritários (construção e expansão de direitos, pelos quais, vimos no item anterior, os movimientos sociais continuam lutando a partir de uma perspectiva emancipatória). Nos anos de 1990, a perspectiva se amplia, os eixos de luta se renovam e se abrem novas fronteiras de alianças e horizontes que acabarian por estabelecer, entre os movimentos sociais, várias coalizões e (ou) redes de movimentos sociais que não se podem que não podem ser esquecidos no estudo do recente fluxo dos movimentos sociais latino-americanos, sobretudo aqueles que intercedem pela transformação social no subcontinente. Não obstante, sob o risco de nos enredar, devido a seu caráter polissêmico, é importante precisar brevemente o conceito de redes, que vem sendo utilizado, nos últimos anos, muitas vezes de forma indiscriminada, tanto por ativistas ou militantes como por estudiosos das ações coletivas.

As redes sociais foram estudadas a partir de diferentes perspectivas, segundo a disciplina em questão e (ou) o objeto a que se aplica, abrangendo um amplo leque de imagens e significados. A expressão "rede", como um sistema de nós interconectados, foi utilizada fundamentalmente para se analisarem aspectos estruturais e (ou) for- mais (Degenne; Forsé, 1994), e foi amplamente revisada e ampliada em estudos já clássicos como o de Castells (1996), no qual, em seus três volumes sobre a Era da Informação, o autor defende que as redes constituem a nova morfologia social de nossas sociedades (em rede), uma morfologia que supõe uma fonte de drástica reorganização das relações de poder, contribuindo para modificar, de forma substancial, a operação e os resultados dos processos produtivos e de experiência, poder e cultura. Para Castells, tudo é rede, razão pela qual abrange, no mesmo marco epistêmico, vários tipos de redes, desde os mercados de bolsas de valores até o tráfico de drogas, passando também pelos movimentos sociais, em que o autor catalão não é capaz, por exemplo, de apresentar um cenário fundamental de tensão ou conflito entre as redes de produção do discurso neoliberal (as quais, segundo ele, naturalizam e estendem as redes à sociedade) e as redes de resistência, como podem ser aquelas tecidas pelos movimentos sociais latino-americanos contra de uma integração regional sob o esquema neoliberal. Como recorda Prado (2001, p. 104), é evidente que, para combater o neoliberalismo, é necessário estar na sociedade em rede e na rede (Internet), mas, no caso das redes de movimentos sociais, não se trata unicamente de estar na rede, mas sim de utilizar a rede para enfrentar o adversário e (ou) inimigo.

Scherer-Warren (2005b, p.35) distingue entre coletivos em rede e redes de movimentos sociais. Segundo a autora, coletivo em rede se refere a conexões numa primeira instância comunicacional, instrumentalizada através de redes técnicas, de vários atores ou organizações, que procuram difundir informações, apoios solidários ou inclusive estabelecer estratégias de ação conjuntas. Por sua vez, as redes de movimentos sociais seriam redes sociais complexas, que transcendem organizações empiricamente delimitadas, e que conectam - de forma simbólica e com laços de solidariedade - sujeitos individuais e atores coletivos, cujas identidades se constroem num processo dialógico. Nesse processo dialógico é onde se forma a identidade do movimento (identificações e convergênci- 
as sociais, éticas, culturais ou político-ideológicas), se define o adversário (entre os intercâmbios, as negociações, o conflito, os mecanismos de dominação, exclusão e resistência) e se marcam os objetivos ou se constrói o próprio projeto político do movimento social.

Compartilhamos com a autora que, para buscar os limites e as imbricações entre coletivos em rede e redes de movimentos sociais, deve-se ir além das análises estáticas das redes como sistemas (já dizia Granovetter, 1973, em sua teorização sobre a força dos vínculos frágeis; aqueles laços que, nas análises estáticas, parecem menos relevantes podem constituir as dimensões-chave para o estudo das redes). Nesse caso, o que nos interessa sublinhar é seu renascimento movimentista contemporâneo, muito imbricado ao atuar em rede, entendida tanto como campo de ação (político-social-cultural) de práticas coletivas, como forma de organização política mais horizontal, que contrasta com a verticalidade e a hierarquização da política tradicional, pensando também o lugar do território em sua constituição.

Outra questão central que subjaz é: as redes de movimento são pré-condição ou resultado da ação coletiva? (Diani, 1998). Poderíamos dizer que uma combinação de ambos, a partir do momento em que, por um lado, a existência de laços fortes e articulados entre os atores é uma pré-condição para o desenvolvimento das mobilizações, mas, por outro, as redes poderiam ser, mesmo que provisoriamente, produtos da ação, numa espécie de efeito de irradiação, onde novos interlocutores e (ou) aliados seriam escolhidos e incorporados depois de uma série de ações.

Também vale recordar, como fez Melucci (1989, p. 60), que não podemos olhar as redes de movimento (ou as áreas de movimento, como as denominava o autor italiano) pensando exclusivamente nas organizações formais, mas dar igual atenção à rede de relações informais que conectam núcleos de indivíduos e grupos a uma área mais ampla de participantes. Dessa idéia se depreende a necessidade de considerar as redes tecidas pelos movimentos sociais latino-americanos num senti- do amplo, já que, com freqüência, tais redes se formam em torno de ameaças e oportunidades de curto prazo, trasformando-se, muitas vezes, em coalizões de papel, ou seja, meros selos dentro da estratégia política transnacional, como desenvolveremos empiricamente no item seguinte. Somente quando as oportunidades e as ameaças persistem no tempo e as coalições desenvolvem fortes identidades subjacentes, elas acabam por converter-se em movimentos sociais (Della Porta; Diani, 1999; Tarrow, 2005, p. 165).

Tarrow (2005), em seu recente estudo sobre o que denomina um novo ativismo transnacional, prefere falar de coalizões transnacionais, já que, mesmo considerando ser necessário distinguir entre o significado estrutural (como um sistema de nós interconectados) e o propositivo (aquelas estruturas nas quais grupos e indivíduos se unem para alcançar determinados objetivos) das redes, esse seria um termo menos significativo ou impactante que coalizões ou movimentos. Para Tarrow, todos os movimentos sociais estão constituídos por coalizões, mas nem todas as coalizões produzem movimentos sociais, e, ainda que a ação das redes ou coalizões transnacionais tenha um alcance internacional, esses movimentos sociais continuam tendo fortes vínculos com o âmbito doméstico.

Notamos, desse modo, que as escalas de atuação das redes transnacionais de movimentos sociais não são rígidas. Atuam, muitas vezes, dentro e fora do território do Estado-nação, pressionando tanto instituições e organizações nacionais e multinacionais, razão pela qual importa pensar o lugar de atuação dessas redes, as sociabilidades e horizontalidades geradas, mas também as estratégias políticas que fomentam sua territorialização e a construção de novas subjetividades coletivas num marco supranacional. Por exemplo, as ações coletivas do MST contra símbolos da globalização neoliberal, como as empresas Bunge ou Monsanto, supõe a construção de uma nova percepção dos militantes do movimento em direção às dimensões supranacionais da problemática da luta pela terra, ao mesmo tempo em que redimensionam a importância de pensar a territorialização dos movimentos 
sociais em suas estratégias de luta (Bringel, 2006).

Após uma marginalidade histórica das dimensões espaciais dentro das teorias dos movimentos sociais, centradas fundamentalmente na história, na psicologia social, na sociologia e na ciência política, vários conceitos de longa tradição geográfica - como território, fronteira, espaço e lugar, as variáveis de escala do local ao global, ou inclusive metáforas espaciais como centro e periferia - emergem com força renovada nas teorias explicativas dos movimentos sociais e das ações coletivas (Bringel, 2007a). Muitas vezes interpretadas com as rígidas barreiras das fronteiras disciplinares, essas aproximações geográficas levaram a posições catastrofistas, como o fim do território (Badie, 1995).

Não obstante, como assinalado anteriormente, negamo-nos a visualizar as redes transnacionais de movimentos sociais como uma mera extrapolação ou salto de escala de atuação dos movimentos sociais locais ou nacionais para a escala transnacional ou global. Tampouco se pode pensar nas redes transnacionais de movimentos sociais como uma forma abstrata de composição do espaço, mas sim como um componente territorial indispensável, que enfatiza a dimensão temporal-móvel do território (Haesbaert, 2006) e que, conjugada com a noção de superfície territorial (base da ação coletiva dos movimentos), ressalta seu dinamismo e suas perspectivas de conexão com outros movimentos sociais, fundada em um objetivo comum de luta em escala transnacional. Observar isso a partir do exame dos casos concretos indicados é o nosso objetivo logo a seguir.

\section{ATERRITORIALIZAÇÃOSUPRANACIONALDOS MOVIMENTOS: O caso do MST e da FUCVAM}

\section{O caso do MST}

Fundado em 1984, o Movimento dos Trabalhadores Rurais Sem Terra (MST) do Brasil, surge no meio de um amplo leque de lutas sociais contra a ditadura militar, ainda que, nesse caso parti- cular, em um cenário de batalhas simbólicas para estender a concientização do acesso à terra como um direito negado. ${ }^{3}$ Desse modo, resgatando nossa segunda premissa apresentada anteriormente, o MST trata de deconstruir, desde seu processo de gestação, a construção subjetiva da resolução de uma necessidade como um direito (o acesso a terra) e não como produto de uma atividade mercantil (lógica que se havia exacerbado entre 1966 e 1984, com o governo militar, e que fomentou a instalação de numerosas empresas multinacionais e a inversão de bancos e construtoras estrangeiras nas zonas rurais do país).

Ante tal construção, poderíamos dizer que, apesar de o MST ter se centrado em organização interna, formação e expansão nacional através da territorialização do movimento, durante sua primeira década de existência (até meados dos anos 1990), a segunda metade da década de noventa marcou o início da sua projeção exterior. Ainda que o espaço central de ação do MST continue sendo o Estado-nação (o espaço social onde se produzem as ocupações, as tensões, a cooperação e o conflito, ou seja, as relações e interações do movimento continuam sendo fundamentalmente o território brasileiro), assim como suas principais demandas continuem sujeitas à territorialidade da política brasileira (a luta pela reforma agrária, por exemplo, continua tendo como principal interlocutor o governo nacional), é cada vez mais perceptível a multidimensionalidade dos processos socio-geográficos, e as articulações entre sociedade e espaço, que redefinem interesses demandas e projeções que vão além do âmbito doméstico.

A década dos noventa marcou um contexto crítico para os movimentos populares no campo, devido à forte onda neoliberal desencadeada na América Latina, o que levou a privatizações, pro-

\footnotetext{
A Carta de Goiânia, do dia 26 de setembro de 1982 dirigida aos companheiros sem terra do Brasil num período de gestação do MST, redatada depois de um Seminário organizado pela Comissão Pastoral da Terra (CPT), já enfatizava a necessidade de lutar pela terra como direito negado. Essa carta, assim como uma breve história do MST e da luta pela terra no Brasil, pode ser encontrada em Morissawa, 2001. Para uma aproximação da formação do MST, a partir de seus processos de territorialização, é imprescindível a obra de Fernandes (1999).
} 
gramas de desregulação e liberalização - e, com isso, à entrada massiva de capital estrangeiro nas zonas rurais. No caso específico do MST, as conseqüências foram muito visíveis, com o incentivo ao agronegócio, à produção de transgênicos em terras brasileiras por empresas transnacionais (o que vai contra a reivindicação de soberania alimentar do movimento), ou a mais recente política de fomento ao monocultivo de cana-de-açúcar para a produção de etanol, também controlada por empresas como Bunge, Syngenta ou Cargil (Bringel, 2007b). As ações coletivas contra essas empresas, símbolos da globalização capitalista, supõem, como afirmávamos anteriormente, a construção de uma nova percepção dos militantes do movimento em direção às dimensões supranacionais da problemática da luta pela terra (Bringel, 2006).

Mas, apesar do contexto generalizado de refluxo da década de noventa (mas não uma "crise terminal" ou um "fim" dos movimentos sociais), foi nessa mesma década que se estabeleceram muitos dos pilares organizativos de resistência regional, num processo de busca de alternativas da sociedade e de convergências de experiências entre os movimentos e organizações camponesas latino-americanas, cada uma delas com diferentes tradições de lutas e resistência, formas específicas de organização, diferentes metodologias, alcances e graus de incidência em seus respectivos âmbitos de atuação. Em 1994, mesmo ano do levantamento zapatista no México, 84 organizações camponesas, procedentes de 18 países da América Latina, criaram a CLOC, como uma instância de convergência para construir uma unidade de ação entre as organizações, com uma estrutura flexível, capaz de captar as realidades dos diferentes países e regiões. ${ }^{4}$

O MST desempenhou - e continua desempenhando - um papel central na constituição e articulação da resistência camponesa em âmbito latino-americano, desde o acolhimento em São Paulo, em 1995, da Primeira Reunião Plenária da

${ }^{4}$ Definição elaborada a partir das linhas básicas definidas na Primeira Plenária da CLOC, realizada nos dias 30 e 31 de março de 1995.
CLOC (precedida do I Curso Latino-americano de Formação), até o impulso posterior, não somente de um espaço de coordenação entre organizações e movimentos, mas de uma rede de dimensões globais, como é a Via Campesina, que já se perfila como o maior referente no plano global das lutas camponesas, tanto no nível de articulação como de mobilização social e de construção de alternativas societárias para as realidades agrárias. No processo de consolidação e expansão da Via Campesina, o MST constitui um eixo central para a difusão de ações coletivas na América Latina, não só por ser formalmente sede da Secretaria Regional desse movimento sul-americano, mas porque, devido à sólida base social construída nos anos anteriores, o MST - o maior movimiento social campesino da América Latina - agrega recursos (sobretudo humanos, sociais, políticos e formativos) fundamentais no aprofundamento dos laços transnacionais entre movimentos.

Além disso, os marcos fundamentais da luta do MST acabaram por carregar de simbolismo a luta campesina em todo o mundo, como é o caso do massacre do Eldorado de Carajás no dia 17 de abril de 1996. O acontecimento, além de ter grande eco fora do Brasil, pela brutalidade dos fatos (19 mortos e 69 feridos graves após uma ação violenta perpetrada pela polícia), se converteria no Dia Internacional da Luta Campesina.

Num contexto de globalização neoliberal, a imbricação das dinâmicas sociopolíticas e a espacialização das lutas e resistências sociais se conectam de forma crescente. Assim, a dimensão transnacional da luta do MST está cada vez mais presente, inclusive na própria mística do movimento. Por exemplo, no V Congresso, realizado em junho de 2007 em Brasília, se encenou um casamento que simbolizava a aliança entre latifundiários nacionais, por um lado, e as empresas e o capital transnacional, por outro. O governo brasileiro aparecia como o padre que dava a benção a essa união, afiançiando a cerimônia. No entanto, o momento mais importante desse casamento se deu no momento do sim, aceito!, quando os camponeses sem terra - que não haviam sido convidados 
para a grande cerimônia-irromperam na cena, denunciando e tratando de impedir tal matrimônio.

Desse modo, após 24 anos de existência do MST, a influência das ações coletivas do movimento vão muito além dos 23 estados brasileiros onde atua, razão pela qual se torna fundamental vislumbrar as redes transnacionais tecidas, as sociabilidades e horizontalidades e as alternativas societárias traçadas, mas também as estratégias políticas que fomentam sua territorialização e a construção de novas subjetividades coletivas num marco supranacional.

Em grandes linhas, poderíamos afirmar que a ação exterior e transnacional do MST está plasmada, fundamentalmente, através de quatro planos ou âmbitos de atuação (Bringel; Landaluze; Barrera, 2008):

a) primeiro, a relação e a articulação duradoura através de espaços e redes transnacionais de organizações e movimentos sociais campesinos (é o caso da CLOC, em âmbito regional, e da Via Campesina, em âmbito global);

b) segundo, a relação permanente com grupos de solidariedade (que recebem diferentes denominações, como Grupos de Amigos ou Comitês de Apoio), localizados principalmente no centro do sistema-mundo - Europa e Estados Unidos -, baseada no internacionalismo e na solidariedade política com o movimento; ${ }^{5}$

c) terceiro, a cooperação político-econômica específica com organizações sociais, instituições e agentes da cooperação internacional públicos (fundamentalmente administrações públicas descentralizadas e universidades) e privados (ONG de desenvolvimento) para a consecução de algum acordo ou projeto específico;

d) quarto, uma articulação mais ampla, em momentos específicos ou contextos particulares, com

5 A maioria desses Comitês de Apoio - que têm como objetivo central a difusão das lutas e experiências alternativas que o MST desenvolve no campo, assim como denúncia de sua constante criminalização - estão localizados na Europa: França, Itália, Suécia, Noruega, Bélgica, Holanda, Alemanha e principalmente no Estado espanhol (onde há Comitês em Barcelona, Madrid, Córdoba, Asturias, Eskaudi e Zaragoza). Também há vários comitês nos Estados Unidos e uma organização incipiente no Canadá e no Japão. organizações político-sociais e movimentos sociais não necessariamente campesinos, em campanhas e espaços internacionais (é o caso do Fórum Social Mundial, por exemplo).

Enfatizamos, até aqui, as principais “redes formais" das quais o MST participa (como a CLOC e Via Campesina) com grande incidência na América Latina. No entanto, o potencial da cooperação reticular do movimento na região é muito mais amplo, e abrange numerosos projetos com organizações e movimentos. São habituais, por exemplo, os projetos transnacionais de educação e formação (como oficinas de agroecologia, formação de médicos do movimento em Cuba, programas de alfabetização de adultos - a exemplo da iniciativa cubana Sim, eu posso - ou dinâmicas de economia solidária e cooperativas propriamente ditas).

Em suma, os intercâmbios e alianças, as redes e projetos de cooperação e solidariedade desencadeados nas últimas décadas apontam em direção de uma crescente dinâmica transnacional inter-movimentos, que, no caso do MST e das lutas campesinas na América Latina, levam a fortes disputas pelo território rural, como espaço político de suas lutas e conflitos, ao mesmo tempo locus da experiência vivida e, num sentido mais amplo, a própria vida dos campesinos: sua mãe, a Pacha Mama. Nesse sentido, as batalhas reais e simbólicas por uma construção social do território rural, que desafie a lógica hegemônica do capital e do ordenamento dominante do espaço, passam a dotar-se de uma articulação transnacional cada vez mais estruturada - como se viu no caso da luta contra a ALCA - que procura romper com as estruturas espaciais que freiam a conquista de direitos.

\section{O caso da FUCVAM}

Foi fundada em 1970, a partir de algumas cooperativas de moradias construídas no interior do Uruguai por setores trabalhadores. Pode-se dizer que a FUCVAM vem se consolidando como um movimiento social urbano que, apesar de alguns ciclos de fluxo e refluxo, já se constitui de 
mais de trezentas cooperativas de base, num total de 16 mil famílias. ${ }^{6}$ A lógica central que caracteriza o movimento é a busca por moradia, entendida como um direito social cujo acesso pode ser resolvido mediante um sistema - dito de forma breve de autoconstrução coletiva, precisamente de ajuda mútua, de autogestão dos núcleos habitacionais e a partir da reivindicação de empréstimos ao Estado e de lugares nas cidades (particularmente Montevidéu) para a construção.

É importante destacar, a nosso ver, que não se trata meramente de uma organização com uma reivindicação particular de empréstimos para a construção de cooperativas de moradia, mas que mostra uma visão da sociedade mais ampla e promove um estilo de vida alternativo, baseado precisamente na cooperação. Examinar como isso se manifesta na prática, as contradições que surgem nessa proposta, e observar, por exemplo, as diferenças de posturas entre quem já acedeu à moradia mediante o sistema e quem luta por terras e (ou) empréstimos para construí-las não deve minimizar a importância da atuação do movimento.

Com seu caráter de organização social, sua presença foi notória em diversas expressões públicas no Uruguai, desde sua participação na recuperação democrática, na década de 1980, à sua incorporação na convocatória para plebiscitos e referendos da década de 1990 e início do novo século. Em geral, as relações com os sucessivos governos foram conflituosas, não apenas com as variantes de centro-direita que se sucederam de 1985 a 2004, mas também com o governo da "Frente Ampla" que assumiu no ano de 2005 e não mostrou nenhuma sensibilidade especial para a proposta.

As conexões internacionais da FUCVAM têm muitos anos. Em alguns casos, provêm do apoio recebido durante a ditadura. É o caso da Confederação Latino-americana de Cooperativas Mutuales de Trabalhadores (COLACOT), uma organização à

${ }^{6}$ Lembremos da escala da população do Uruguai: aproximadamente três milhões trezentos mil habitantes; a metade da mesma concentrada em Montevidéu e a região metropolitana. Para mais dados neste sentido, ver: Instituto Nacional de Estadística: www.ine.gub.uy qual continua vinculada formalmente, apesar de a afinidade político-filosófica não ser muito estreita (dito em linhas gerais, orientação cristã, no primeiro caso, orientação socialista, no segundo). Desde o final da década de oitenta, estabeleceramse conexões com o Centro Cooperativista Sueco mais substantivas que no caso anterior. Em 1994, a FUCVAM entra formalmente na Coalizão Internacional para o Hábitat (HIC), relação que se aprofunda no marco preparatório da segunda Cúpula de Assentamentos Humanos (Habitat II), realizada em Estambul, em 1996.

Ademais, a organização se apresenta cultivando a prática do internacionalismo com trabalhadores e cooperativistas. Com efeito, desde os anos 1980, foi tecendo diversas conexões no âmbito latino-americano. Um resultado desse processo foi a criação da Secretaria Latino-americana da Moradia Popular (SELVIP), da qual a FUCVAM é membro fundador, que se expressou publicamente contra o projeto ALCA, impulsionado fortemente, há alguns anos, pelos Estados Unidos. Mas pode-se afirmar que, como no caso do MST, os processos de conexão transnacional se desenvolveram mais decisivamente em âmbito regional na década de 1990, coincidindo com a afirmação do processo de integração regional do Mercosul.

O avanço ante a necessidade de tecer redes transnacionais com os países mais próximos decorreu da avaliação de uma situação muito heterogênea na região, no que se refere à legislação de acesso à moradia popular, em que a mais avançada - apesar de restrições - era precisamente a uruguaia. No caso paraguaio, observa-se que não havia nada similar, com exceção de um fundo nacional de moradia sem nenhum resultado efetivo, e ademais - em sintonia com a construção sóciohistórica do Paraguai no século XX - corrompido. Na Argentina, existiam regulamentações provinciais que regulavam o acesso à moradia de setores populares, enquanto que, no Brasil, há algumas iniciativas estaduais, mas, igualmente ao caso anterior, sem legislação nacional.

Considerando essa heterogeneidade, aperfeiçoar instrumentos de acesso à moradia popular, 
na região, era visto pelo movimento como um tema de importância para o futuro. Isso supõe a busca de grupos com capacidade de organização em países vizinhos, assim como a construção de nexos regulares com os uruguaios assentados no exterior (especialmente arquitetos), com os quais se podiam gerar algumas articulações. Desencadeia-se, assim, um processo de construção de um tecido regional.

No caso do Brasil, a aposta foi com a "União Nacional de Moradia”, com bases em São Paulo, Belo Horizonte e Porto Alegre, o que permitiu a construção de moradias pelo sistema de ajuda mútua. No caso argentino, a FUCVAM encontrou um interlocutor no Movimento de Ocupantes e Inquilinos (MOI), surgido no centro histórico de Buenos Aires, que ocupava hotéis e casas abandonadas. Também houve, durante um determinado período, uma relação fluída com a Federação de Terras e Moradia da central de trabalhadores CTA (Central de Trabalhadores Argentinos). Isso possibilitou, por exemplo, que integrantes dessa organização estivessem presentes em atos públicos, no Uruguai, contra as privatizações que tiveram impulso na década de 1990. Finalmente, com o Paraguai, os nexos se dão com a chamada Mesa coordenadora de cooperativas de moradia, ainda que um vínculo mais técnico fosse estreitado com o CIPAE (Comitê de Igrejas para Ajudas de Emergências), uma ONG de Assunção que coordenou famílias sem moradia em situação de pobreza.

O intercâmbio com outras sociedades e a transferência da experiência cooperativa na moradia se ampliou nos últimos anos, passando-se a uma escala mais latino-americana, com experiências na América Central: El Salvador, Guatemala, Honduras e Nicarágua. Mas deve-se considerar que o processo de construção e consolidação desse tipo de intercâmbios é complexo e pode limitar-se ou potencializar-se em função das realidades de origem e destino e das conjunturas das lutas sociais vivenciadas. Por exemplo, no caso de Cochabamba, na Bolívia, estima-se que a luta contra a privatização da água enriqueceu o processo organizativo para a construção cooperativa.
Em suma, a evolução na geração de programas participativos para a construção de moradias (particularmente com o apoio do cooperativismo sueco) supôs a geração de fluxos permanentes, não somente na escala do Mercosul. Disso decorre que as ações não estão restritas ao acompanhamento ou monitoramento do que ocorre no exterior, ou à mera comunicação eletrônica. Essas conexões transnacionais foram além de reuniões de dirigentes e de declarações públicas, próprias das convergências sindicais regionais dos últimos anos, sendo possível observar a geração de redes transnacionais de intercâmbio concretas e fluídas - ainda que, no caso da FUCVAM, incipientes. Tais conexões também supuseram apoios para ações específicas para além do terreno da moradia concreta. ${ }^{7}$ Além do mais, o intercâmbio de núcleos de cooperativas entre países, socializando-se em outras realidades, fomentou o conhecimento sobre as experiências concretas, as limitações e as possibilidades.

Ainda que não seja possível definir a conjuntura atual como de intercâmbios fluídos, se observarmos o processo como um todo, poderemos visualizar - tanto em contatos formais como informais - uma perspectiva que começa a construir subjetivamente o problema da moradia como um direito social que transcende as fronteiras de um Estado-nação em particular. Ou seja, comparativamente com o que existia nesse plano no começo da década de 1990, identifica-se um emergente tecido regional - principalmente baseado em algumas experiências coletivas concretas - e uma busca de plasmar uma subjetividade social cooperativa e trans-fronteiriça sobre o direito à moradia, tendente a limar assimetrias de recursos e de organização e a conformar instrumentos legais mínimos.

Nesse sentido, considerado todo o período para além de conjunturas, não se pode considerar o dado como um conjunto de meros intercâmbios

\footnotetext{
Vale lembrar, por exemplo, que membros da FUCVAM estiveram presentes no V Congresso do MST, realizado em Brasília, como forma de apoio e intercâmbio de experiências de lutas no âmbito latino-americano, assim como na busca de expandir a construção de laços entre organizações sociais na região.
} 
descontínuos, mas como uma sucessão de batalhas práticas e simbólicas regionais para estabelecer a importância do dereito a uma moradia digna e do instrumento cooperativo-e, no possível, autogestionário - considerando as variantes culturais regionais sobre o trabalho coletivo. Ou seja, o processo permite que não passem desapercibidas as diferenças entre as sociedades sobre a construção subjetiva do coletivo (por exemplo, são conhecidas as dificuldades da sociedade venezuelana para avançar na concreção de formas de auto-organização).

Tanto as experiências uruguaias como as de âmbito regional, ainda sem haver desencadeado uma dinâmica sustentada, podem ser vistas como pequenas batalhas práticas e simbólicas por outra construção social do território urbano. Pois, ao construirem um território como espaço de resolução coletiva de uma necessidade como a moradia, também se separam da lógica mercantil hegemônica e se transformam - potencialmente - no espaço onde se desenvolvem novas racionalidades. As redes transnacionais, nesse plano, promovem uma abertura (no momento, tão somente abrem, mas isto não é menos importante) para o conhecimento e para o intercâmbio de outros referentes simbólicos e práticos e para a possibilidade de potencializar dinâmicas alternativas de enfrentamento das lógicas hegemônicas de construir subjetivamente o acesso à moradia como uma questão de resolução individual, em função da disponibilidade de recursos.

\section{REFLEXÕES FINAIS. ESPACIALIDADES CONTRA-HEGEMÔNICAS E PROJEÇÕES EMANCIPATÓRIAS NA AMÉRICA LATINA}

A partir da década de 1990, começa a se estruturar uma articulação reticular de organizações e movimentos sociais na América Latina, com experiências de organizações coletivas - tão diferentes como as que foram assinaladas aqui, do MST no Brasil e da FUCVAM no Uruguai - que transcendem os limites do Estado-nação para constituir um marco de resistência espacial supranacional na região. A organização mais isolada ou unidirecional dos movimentos rurais ou urbanos na América Latina, típica de décadas anteriores, dá lugar a um cenário emergente de convergência de ações coletivas, novas formas organizativas, interesses e interações transfronteiriças e emancipatórias. Não somente se supera o Estado-nação como marco referencial para a política dos movimentos sociais, como se atenua a tensão fundamental entre Estado e movimento social, a partir do momento no que o primeiro deixa de ser visto como o único locus relevante da contenda política, num processo de identificação de novos interlocutores e inimigos frontais, relações de poder e dominação.

Ao analisar os casos do MST e da FUCVAM - aparentemente tão diferentes -, procura-se questionar os próprios limites da divisão entre o rural e o urbano na constituição das redes transnacionais de movimentos sociais. Muitas das redes transnacionais tratam de denunciar que, da mesma forma que existe dominação no espaço urbano (locus central das reflexões sobre o espaço desde a década de 1970), também há exploração e dominação no espaço rural, buscando suas imbricações e contribuindo para deconstruir um modelo dicotômico entre campo e cidade, ou entre movimento social rural e movimento social urbano, quando vistos conjuntamente na cena internacional. ${ }^{8}$ Independentemente de esses movimentos terem como base o âmbito rural ou urbano, e de se ter em conta tanto suas especificidades como o atual ciclo capitalista (que revela, por exemplo, uma nova divisão do trabalho, cuja espacialidade pode contribuir para vislumbrar as novas formas de atuação e exploração das grandes corporações, mas também suas resistências), a conexão transnacional de

\footnotetext{
${ }^{8}$ Um dos autores que mais inspiraram as análises sobre movimentos sociais urbanos na América Latina foi Castells, a partir de La question urbane (1972). Aluno de Touraine, mas também de Lefebvre, o autor catalão incorporou nesse texto uma análise dos movimentos sociais a partir de uma dialética socio-espacial. Mesmo que ainda exista uma nítida distinção de enfoques nas análises dos movimentos sociais urbanos e rurais, as redes transnacionais de movimentos sociais parecem articular, em alguns casos, ambas as dimensões, de modo a projetar objetivos concretos, mas de longo alcance, em lutas sociais na esfera transnacional (um claro exemplo seria a articulação de movimientos rurais como o MST e urbanos como FUCVAM, numa luta ampliada como a que se desenvolveu contra a ALCA).
} 
suas ações procura iluminar uma dominação que atravessa tanto o campo como as cidades, e a necessidade de se tecerem alianças mais amplas, com o objetivo de construir alternativas de sociedade e projetar novos eixos de resistência regional, no caso latino-americano.

Pode-se observar, nesse sentido, que os territórios nacionais são também cada vez mais espaços da economia internacional. Da mesma maneira, é preciso observar os territórios nacionais como potenciais espaços de convergências de movimentos sociais de diferentes países nos quais é possível concretizar projetos. Considera-se que o neoliberalismo também se desenvolveu em função de sua eficácia simbólica de conectar proposta e realidade, além das trágicas conseqüências sociais conhecidas. Também se deve considerar que a potencialidade de conexões, como as que foram analisadas, está na eficácia simbólica de conectar propostas de resolução de necessidades alternativas com realidades sociais complexas e diferentes.

Assim mesmo, ao examinar os casos do MST e FUCVAM, observa-se que o caráter antisistêmico das redes transnacionais é também o de disputar o caráter meramente técnico em que alguns atores pretendem circunscrever a construção de um processo de integração regional. Do mesmo modo que a conformação de um Estado-nação constitui um processo de produção e apropriação de discursos e de estruturas cognitivas, como diria Bourdieu, produtos originados a partir das lutas pelo controle do poder simbólico, finalmente, tornam possível o processo, isto é, lhe dão forma.

Como espaço social em construção, o plano macro-regional pós-nacional também alberga projetos diferentes e conflitos entre o sistêmico e o antisistêmico que precisam ser notados. Como vimos, é patente, por exemplo, que a resolução de uma necessidade como o acesso à terra ou à moradia pode ser construída socialmente como um direito, com um sentido emancipatório frente ao projeto do capital que propõe instalar o tema em seu sentido regulatório, mercantilizado. Desse modo, quando se extrai, da lógica puramente mercantil, uma necessidade social e se intercambiam experi- ências, saberes e propostas, trava-se uma disputa pela subjetividade coletiva que também chega ao plano transnacional. Isso supõe um processo lento e complexo de (re)elaboração de significados, mas, quando fundamentado em experiências concretas e crescentes para a resolução prática de necessidades sociais, a potencialidade do alternativo se concretiza socialmente.

No entanto, a significação desse espaço tecido pelos atores coletivos envolvidos não deve ser buscada necessariamente na sua atuação permanente ou na visibilidade através de ações de protesto, já que a indeterminação e a inestabilidade são próprias da sociedade atual. Em grande medida, a transcendência se encontra em sua capacidade de resignificar necessidades sociais com uma perspectiva para além do Estado-nação e nas capacidades de concreção que possam alcançar. Por isso, quando falamos dessas redes, buscamos igualmente superar o plano das reuniões e da conformação de organizações regionais ou globais formais, como os casos da Via Campesina ou SELVIP, para considerar um conjunto de novas horizontalidades, de relações informais, no aspecto propositivo (em abstrato) de abertura para uma sociedade mais igualitária e participativa, frente a perspectivas de uma sociedade onde o limite implícito é o princípio dominante, hierarquizado, do direito à propriedade privada.

Em suma, trata-se de um processo de construção de hegemonia - como apropriação de elementos de transformação social - própria do século XXI, em que o regional e o global aparecem mais imbricados e adquirem maior peso a partir das lógicas dominantes do capital, o que leva, além do mais, à necessidade de sistematizações mais amplas que permitam caracterizar as potencialidades alternativas dessas redes pós-nacionais. A aproximação sócio-territorial aqui apresentada para pensar as redes transnacionais de movimentos sociais na América Latina tem essa aspiração, ao articular um olhar sociológico - com os agentes sociais participantes nessas redes, o espaço social do qual emergem, as práticas sociais e ações coletivas que realizam, as subjetividades coletivas e as dinâmi- 
cas que desencadeiam - com um ângulo geográfico que seja capaz de traçar a convergência transnacional de suas práticas, as horizontalidades, sociabilidades e territorialidades construídas, a partir do espaço socialmente produzido.

(Tradução de Consuelo Brito de Freitas)

(Recebido para publicação em junho de 2008)

(Aceito em agosto de 2008)

\section{REFERÊNCIAS}

ANDERSON, Perry. Las antinomias de Antonio Gramsci. Cuadernos del Sur Buenos Aires, n. 6, 1987.

Las antinomias de Antonio Gramsci. Cuadernos

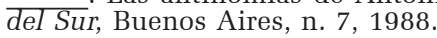

ARDITI, Benjamín. El devenir-otro de la política: un archipiélago post-liberal. In: (Org.) ¿Democracia post-liberal? El espacio político de las asociaciones. Barcelona: Anthropos, 2005. p. 219-248,

BADIE, Bertrand. La fin des territoires. Paris: Fayard, 1995 BORDIEU, Pierre. El sentido práctico. Madrid: Taurus, 1997.

. O poder simbólico. Rio de Janeiro: Ed. Bertrand, 2005.

; EAGLEATON, Terry. Doxa y vida cotidiana. New Left Review, Madri, Ediciones Akal, n. 0, 2000. (Edición en castellano)

BRINGEL, Breno. El lugar también importa. Las diferentes relaciones entre Lula y el MST. Revista NERA, São Paulo, UNESP, v.9, n. 9, jul./dez., p. 27-48, 2006.

O lugar nos movimentos sociais e o lugar da geografia na teoria dos movimentos sociais. Boletim Goiano de Geografia, Goiana, Universidade Federal de Goiás, v.27, n.2, jan./jun., p. 35-49, 2007a.

El V Congreso de los sin tierra reafirma su autonomía frente a Lula. Diagonal Periódico, Madrid, n.58, jul., 2007b. Disponible en: www.diagonalperiodico.net/ spip.php? article4274. Acesso em: 19 abr., 2008.

BRINGEL, Breno; ECHART, Enara; LÓPEZ, Sara. Del actor en movimiento a los movimientos en acción. La rearticulación de la lucha antiglobalización. En: IBARRA, Pedro; GRAU, Elena (Org.). Anuario de movimientos sociales 2008. Barcelona: Içaria; Betiko Fundazioa, 2008. p.178-188.

; LANDALUZE, Jon; BARRERA, Milena. Solidaridades para el desarrollo. La política de 'cooperación activista’ con el MST brasileño. Revista Española de Desarrollo y Cooperación. Madrid, IUDC, n.22. p.195209, primavera/ verano, 2008.

CASTELLS, Manuel. La question urbaine. Paris: Maspero, 1972.

The power of identity. Baltimore: The Johns Hopkins University Press, 1996.

COHEN, Jean; ARATO, Andrew. Civil society and political theory. Massachusetts: MIT Press, 1992.

COUTINHO, Carlos Nelson. Cidadania e modernidade. Perspectivas: revista de Ciências Sociais, São Paulo, Universidade Estadual Paulista, n.22, 1999.
DEGENNE, Alain; FORSÉ, Michel. Les réseaux sociaux. Une approche structurale en sociologie. Paris: Armand Colin, 1994.

DELLA PORTA, Donatella; DIANI, Mario. Social Movements. Oxford: Blackwell, 1999.

DIANI, Mario. Las redes de los movimientos: una perspectiva de análisis. In: IBARRA, Pedro; TEJERINA, Benjamín (Org.) Los movimientos sociales. Transformaciones políticas y cambio cultural. Madrid: Trotta, 1998. p.243-270.

ECHART, Enara. Movimientos sociales y relaciones internacionales. Madrid: Catarata - IUDC, 2008. No prelo.

FALERO, Alfredo. Diez tesis equivocadas sobre la Integración Regional en América Latina. En: VV.AA. (Org.) Pensar a contracorriente II. La Habana: Editorial de Ciencias Sociales, 2006. Disponible en: www.cubaliteraria.com/premio/contracorriente/esp/ premio_11.html.

Movimientos sociales, construcción de subjetividades colectivas y nuevos procesos sociopolíticos: un análisis sociológico a partir de los casos de Brasil y del Cono Sur. Revista Ciências Sociais Unisinos, São Leopoldo-RS, Unisinos, v.43, n.2, maio/ago., p.127-135, 2007.

. Las batallas por la subjetividad: luchas sociales y construcción de derechos en Uruguay. Una aproximación desde la teoría sociológica. Montevideo: CSIC; Ed. Fanelcor, 2008.

FERNANDES, Bernardo. MST. Formação e territorialização. 2.ed. São Paulo: Hucitec, 1999.

GRAMSCI, Antonio. La política y el Estado moderno. Buenos Aires: Planeta, 1985.

GRANOVETTER, Mark. The strength of weak ties. American Journal of Sociology, Chicago, University of Chicago Press, v.78, n.6, p.1360-1380, 1973.

HAESBAERT, Rogério; PORTO-GONÇALVES, CarlosWalter. A nova des-ordem mundial. São Paulo: Ed. UNESP, 2005.

O mito da desterritorialização - do fim dos territórios à multiterritorialidade. Rio de Janeiro: Bertrand Brasil, 2006.

KALDOR, Mary. La sociedad civil global. Barcelona: Tusquets, 2005

LEON, Emma; ZEMELMAN, Hugo. Subjetividad: umbrales del pensamiento social. Barcelona: Anthropos; UNAM, 1997.

MARSHALL, T.H.; BOTTOMORE, Tom. Ciudadanía y clase social. Madrid: Alianza Editorial, 1998.

MELUCCI, Alberto. Um objetivo para os movimentos sociais? Revista Lua Nova, São Paulo, CEDEC, n.17, jun. p.49-66, 1989 .

MILANI, Carlos; LANIADO, Ruthy. Transnational social movements and the globalisation agenda: a methodological approach based on the analysis of the World Social Forum. Working Paper, Rio de Janeiro, Edelstein Center for Social Research, n. 5, dec., 2006.

MORISSAWA, Mitsue. A história da luta pela terra e o MST. São Paulo: Expressão Popular, 2001.

NEGRI, Antonio. El poder constituyente. Madrid: Editorial Libertarias; Prodhufi, 1994.

PORTO-GONÇALVES, Carlos-Walter. Geo-grafías. Movimientos sociales, nuevas territorialidades y sustentabilidad. México D.F.: Siglo XXI, 2001.

PRADO, José Luiz Aidar. O enredo globalizante de Castells. In: PRADO, José Luiz Aidar; SOVIK, Liv (Org). Lugar 
global e lugar nenhum: ensaios sobre democracia e globalização. São Paulo: Hacker Editores, 2001.

QUIJANO, Anibal. Modernidad, identidad y utopía en América Latina. In: LANDER, Edgardo (Ed.) Modernidad y universalismo. Caracas: UNESCO; Universidad Central de Venezuela; Editorial Nueva Sociedad, 1991.

SANTOS, Boaventura Sousa. De la mano de Alicia. Lo social y lo político en la posmodernidad. Bogotá: Ediciones Uniandes; Universidad de los Andes, 1998.

SANTOS, Milton. Economia espacial: críticas e alternativas. São Paulo: EDUSP, 2003.

Da totalidade ao lugar. São Paulo: EDUSP, 2005.

SASSEN, Saskia. ¿Perdiendo el control? La soberanía en la era de la globalización. Barcelona: Bellaterra, 2001.

SERRANO, Enrique. Modernidad y sociedad civil. In: OLVERA, Alberto (Coord.) La sociedad civil. De la teoría a la realidad. México: El Colegio de México, 1999.
SCHERER-WARREN, Ilse. Redes de movimentos sociais. 3.ed. São Paulo: Loyola, 2005a.

Redes sociais: trajetórias e fronteiras. In: DIAS Leila Christina; SILVEIRA, Rogério Leandro (Org). Redes, sociedades e territórios. Santa Cruz do Sul: EDUNISC, pp. 29-50, 2005b.

TARROW, Sidney. The new transnational activism. Cambridge: Cambridge University Press, 2005.

ZEMELMAN, Hugo. De la historia a la política. La experiencia de América Latina. México: Siglo XXI, 1989. Los horizontes de la razón. Barcelona: Ed. Anthoropos; El Colegio de México, 1992. 2 tomos.

Problemas antropológicos y utópicos del conocimiento. México: El Colegio de México, 1996

\section{TRANSNATIONALNETWORKSOF SOCIAL MOVEMENTS IN LATIN AMERICAAND THE CHALLENGE OF ANEWTERRITORIAL CONSTRUCTIONSOCIAL}

\author{
Breno Bringel \\ Alfredo Falero
}

The present paper starts from two considerations: the need to establish an interdisciplinary dialogue between geography and sociology on the problem of territory and of the spatiality of politics; and the verification that the construction of transnational networks of organizations and social movements constitute a key dimension in the current latin american processes. By the light of those considerations the authors examine the transnational networks built from social movements in Latin America, based in a social and territorial focus. Under this perpective are analizados the Movimento dos Trabalhadores Rurais Sem Terra - MST (in englis, Landless Rural Workers Movement), from Brasil e a Federação Uruguaia de Cooperativas de Moradia por Ajuda Mútua-FUCVAM (in english, Uruguayan Federation of Cooperatives for Home Building through Mutual Help) , from Uruguay. In this analysis will be observed the challenges, the formation of anti-hegemonic spaces and the convergences faced by experiences of this nature in the search for emancipatory projections, in the XIX century.

KEYwords: social movements, networks and supranational rights, territorialities, hegemony, Latin America.

\section{LESRÉSEAUX TRANSNATIONAUXDES MOUVEMENTS SOCIAUX EM AMÉRIQUE LATINE ET LE DÉFI D'UNE NOUVELLE CONSTRUCTIONSOCIO- TERRITORIALE}

\author{
Breno Bringel \\ Alfredo Falero
}

Deux considérations servent de point de départ à cet article: le besoin d'établir un dialogue interdisciplinaires entre la géographie et la sociologie quant à la problématique du territoire et de la spatialité de la politique ; et le fait de constater que la construction de réseaux transnationaux d'organisations et de mouvements sociaux constituent une dimension-clé dans les processus latino-américains actuels. A la lumière de ces considérations, les auteurs analysent les réseaux transnationaux construits à partir des mouvements sociaux en Amérique Latine, en se concentrant sur l'aspect socio territorial. C'est sous cet angle-là que le Mouvement des Travailleurs Ruraux Sans Terre - MST, au Brésil, et la Fédération Uruguayenne des Coopératives d'Habitation d'Aide Mutuelle- FUCVAM, en Uruguay, sont analysés. On observera dans cette analyse les convergences, la formation d'espaces anti-hégémoniques et les défis à affronter au cours de telles expériences pour la recherche de projections émancipatoires au $19^{\mathrm{e}}$ siècle.

Mots-CLÉs: mouvements sociaux, réseaux et droits supranationaux, territorialités, hégémonie, Amérique Latine. 